\title{
Biomechanical and organizational risk and prevalence of low back pain in the old adults caregivers of a nursing home in Joao Pessoa/PB
}

\author{
Sânzia Bezerra Ribeiro ${ }^{\mathrm{a},{ }^{*}}$, Maria Claudia Gatto Cárdia ${ }^{\mathrm{b}}$, Lais Cristina Almeida ${ }^{\mathrm{c}}$ \\ ${ }^{a}$ Faculdade Adventista da Bahia, Bahia, Brazil \\ ${ }^{b}$ Universidade Federal da Paraíba, Paraíba, Brazil \\ ${ }^{c}$ Escola Brasileira de Osteopatia, Brazil.
}

\begin{abstract}
The objective present study was to investigate the presence of low back pain in caregivers of a nursing home, related with the labored activities executed by these workers. 16 subjects were investigated, 15 female and one male, with 40,8 age average all being caregivers as their profession. It consisted of three phases, where the first concerns the analysis of the collective work, assessed in a perspective of caregivers, Second, a postural assessment to verify the retractions in such workers and the third stage was used Diagram of Corllet to identify the presence of signs and symptoms in caregivers. The study demonstrated that organizational and biomechanical factors are responsible for the high level of physical fatigue and presence of pain in $93,75 \%$ of the caregivers in some region of the body. $50 \%$ referred pain in the lumbar region. The results of the postural evaluation confirmed that the caregivers had alterations in the postural alignment, presenting retractions of the anterior and posterior chain. The suggestions are to minimize the risk factors of this productive process and the symptoms and signals presented from these workers by adoption ergonomic measures and the realization of a physical program with stretching and muscular strengthening of the muscles of thee anterior and posterior body chain based on the method of Reorganization Postural Sensoperceptive .
\end{abstract}

Keywords: low back pain, caregivers, enderly, overload work

\section{Background}

The health of caregivers of elderly has been a subject much discussed lately, due to increased population over 65 years, so it is important to correlate this fact the responsibility of teams of health professionals and their [22].

The work of caregivers for the elderly in nursing home and a difficult and demanding activity that requires much physical effort of work and the psycho-emotional disorders, since caregivers often engage elderly, causing physical overload, in addition to psychological factors activity involving the care, adding to the physical stress that worker, psycho-emotional stress [9, 28].

The work of caregivers for the elderly in nursing home and a difficult and demanding activity that requires much physical effort of work and the psycho-emotional disorders, since caregivers often become involved with the situation of the elderly dependent $[25,9,11]$. 


\begin{abstract}
BR 101, KM 197, CAIXA POSTAL 18, Capoeirucu, Cachoeira/BAs
Thus, these workers are exposed to biomechanical
risk, which may contribute to the development of Work-related musculoskeletal disorders (WRMD) , especially damage to the spine (especially the lumbar region), by repetition of movement or an overload of work, remaining very time in the position of front tilt (flexion) in handling the care of the elderly [25].

Such action triggers a set of signs and symptoms that reflect changes in postural alignment, and expose you to a state of physical and mental stress that can rule out the professional work or even let it unproductive $[21,9,11]$. Given the above, this study aims to investigate the biomechanical and organizational risks in caregivers of elderly in a nursing home and its relation to the presence of pain and other symptoms.
\end{abstract}

\section{Methods}

It is a field study, observational crosssectional, which were investigated, initially, 15 females and one male, aged 23 to 67 years and have a caregiver activity as an occupation. The methodology used in this study consisted of three phases, where the first one refers to the collective analysis of the work process, evaluating caregivers' perspective, the activities undertaken by them along the way, its facilities and difficulties, the risks attendant in the workplace and its relationship to the safety and health, thus tracing a profile of activity of the caretaker of the institution under study. To fulfill this first step we used a portable tape recorder to collect information and then transcribe them, analyzing the responses of each caregiver. Secondly, there was a postural physiotherapy assessment to check the retractions present in these workers, as well as the conduct of tests for the previous and posterior according to the method REPOSTURARSE (Sensory-Perception Postural Reeducation) [2]. In the third step we used the diagram Corllet (1976), modified by Cardia (2002) and adapted by Neto (2004) [23] to identify signs and symptoms such as pain, tingling, burning, heaviness, among others, locating them in human body. Corllet's diagram is shown in Figure. 1. Still held the application of semi-structured form, containing questions related to intensity, frequency, type of pain and its relation to activities of daily living and labor.

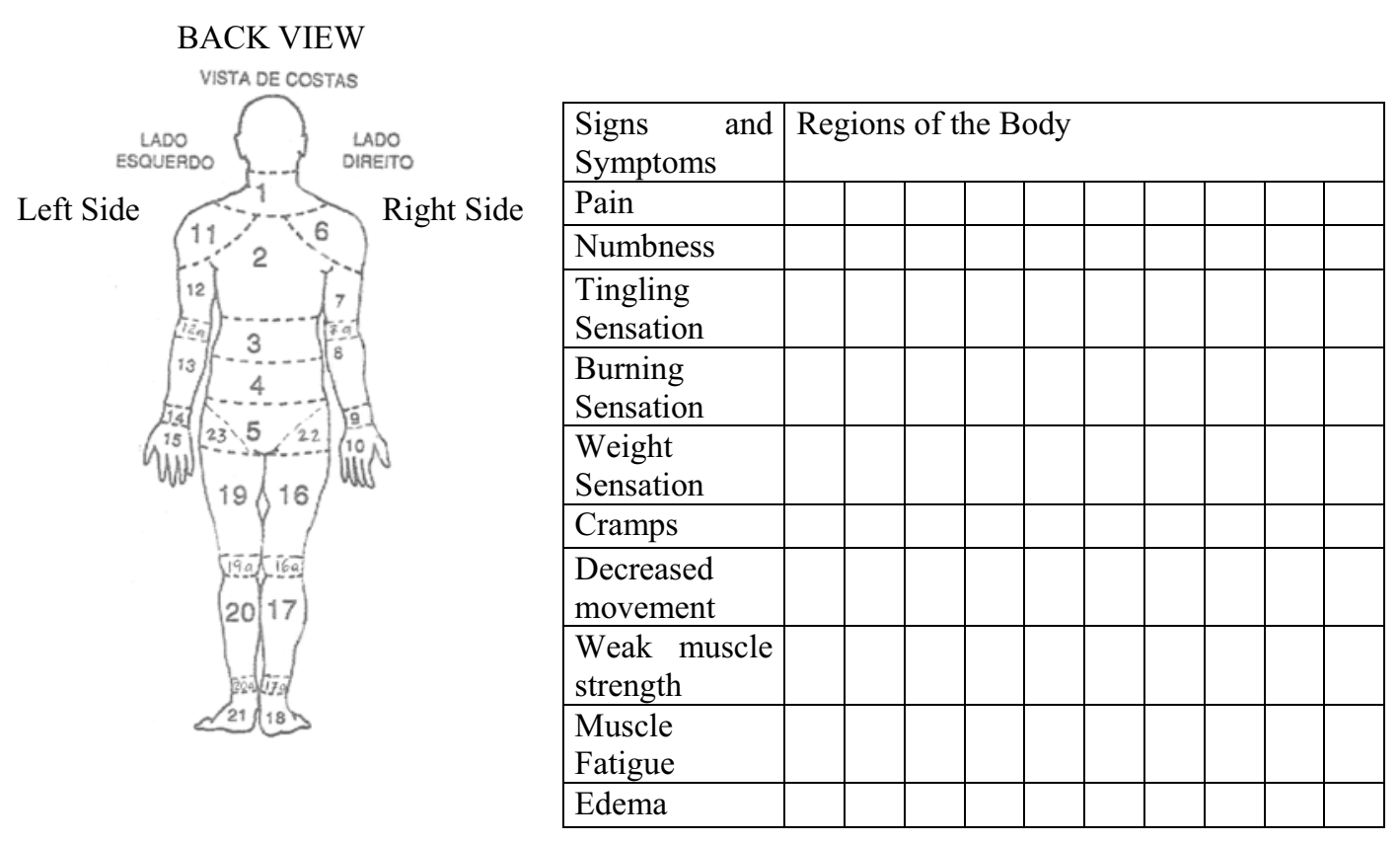

Figure 1: CORLETT'S DIAGRAM: LOCAL SIGNS AND SYMPTOM NEURO-MUSCLE SKELÉTAL Adapted by NETO (2004), grounded in CORLETT e BISHOP (1976) modified by OSHA(2000) and CARDIA (2002) 


\section{Results}

\subsection{Profile of caregivers}

16 caregivers participated in the study were 15 female and 1 male, mean age of 40.8 years and average length of service of five years. With respect to marital status, $37.5 \%$ are married, $18.75 \%$ (3) single, $12.5 \%$ were widowed and only one caregiver is separate.

Regarding schooling, 25\% (4) of the caregivers are illiterate, $25 \%$ have finished elementary school, $37.5 \%$ (6) the elementary school, $12.5 \%$ (2) the school, and $65 \%$ (1) complete high school. Regarding life habits, 56.25\% (9) of caregivers did not smoke, $25 \%$ always and only smoke a caregiver sometimes reported smoking and $50 \%$ of participants drank. No caregiver practices physical activity and $50 \%$ have difficulty sleeping.

The predominance of females, the married state and the mean age less than 50 years among caregivers and corroborated data others studies showing that women have the activity of caring in role of historical roots, cultural, social and affective [11, 21, 25].

A higher level of education may be one factor that contributes to improving the quality of medical care, encouraging the development of these activities [11].

Together with the ease and sedentary habits, stress factors at work that make people's lives become increasingly favorable for the acquisition of psychosomatic illness and physical weakness of immunity [26].

\subsection{Description of the caregiver activity}

The work of caregivers for the elderly is performed by 17 employees, distributed in two shifts, and one group starts the journey at 7:00 am going until 4:00 pm and another group starts at 9:00 am until 7:00 pm.

They work on a sliding scale system, changed every month, 6 days a week (one week off), including Saturdays, Sundays and holidays. The nursing home is subdivided into two wards, male and female, with most employees working in the female wing, which demands increased workload. All are employed by the system of service, unregistered, receiving a minimum wage at the town hall and a bonus paid by the institution at the time amounted to $\mathrm{R} \$ 65.00$. The institution also offers such benefits, food and transportation vouchers. In addition to the caregivers, the nursing home has three licensed practical nurses, a physiotherapist, a driver and director.

Caregivers are responsible for 86 elderly people performing the activities of bathing, preparing meals, serve them, cleaning and laundry facilities. The work routine is described in Table 1 :

Table 1

Work rotine (caregivers elderly)

\begin{tabular}{|c|c|}
\hline Time & Activies \\
\hline 7:00am & Elderly Bath \\
\hline 8:30am & $\begin{array}{l}\text { Breakfast (first elderly after } \\
\text { caregivers) }\end{array}$ \\
\hline 9:00am & Cleaning elderly rooms \\
\hline 11:00am & $\begin{array}{l}\text { Lunch (almost dependent to } \\
\text { the function) }\end{array}$ \\
\hline $12: 00 \mathrm{pm}$ & Break to lunch (caregivers) \\
\hline 01:00pm & $\begin{array}{l}\text { Cleaning Kitchen, clothes } \\
\text { (laundry) }\end{array}$ \\
\hline 03:00pm & Snack \\
\hline 04:00pm & Bath (elderly) \\
\hline 05:00pm & Elderly Dinner \\
\hline
\end{tabular}

When asked to define the work of the same caregiver was defined as "nice", "heavy", "repetitive," "tiresome", "boring" "creative" and "painful." They claim to like the work by issuing the relationship with the elderly as being the biggest motivator for implementing the same, which justifies using the words "pleased," "motivated," "joyful," "confident" and "held" to define the sensations present at the end of exhaustive work day. They also reported feelings of anxiety, fatigue and pain as present both before starting the journey and at the end of it. All caregivers reported feeling physically tired at the end of the workday. When asked if the work somehow interfered in his family relationship, 62.5\% (10) responded affirmatively, explaining that the fact that they worked on weekends, public holidays, with only a weekly holiday, besides the heavy load of physical work hinders their social relations. All were unanimous in reporting as suggested changes in work organization, work being cited in a single turn, or every other day or even an increase in the number of employees to thus minimize the effects of work overload. The activity of the same caregiver requires a high burden of physical labor, since all caregivers report feeling physically tired at the end of the journey. corroborated others studies [21[9][11]. One study with 20 caregivers, where $75 \%$ reported feeling tired physically [11]. The study showed that organizational factors such as workload, work on weekends and holidays was reported by caregivers as responsible for the high level of physical fatigue, and the postures adopted by them along the journey. Others studies [17] [13] [1] showed states that overtime, shift folds, work on Saturdays, Sundays and holidays are work organizational factors that contribute to work 
overload and may be accompanied tension overload, according to interfere with aspects of private life of the worker. The maintenance of poor posture in labor activities, produce workers tense and stiff muscles, back pain, constant fatigue and lack of enthusiasm for their activities [7].

\subsection{Postural assessment}

It was quantified the presence of retractions of previous (front) chain (RCP), back chain (RCB) and decreases in all other caregivers assessed, where $50 \%$ of caregivers had more RPC, over $25 \%$ and $18.75 \%$ RPC (3) showed the same decreases the amount of $\mathrm{PC}$ and $\mathrm{BC}$. The shoulder wound was the type of RCP more often with $93.75 \%(15$,$) according to Figure 2$ shows.

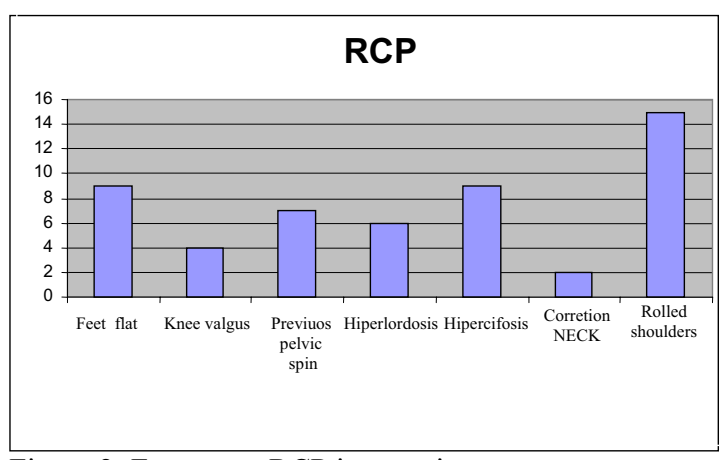

Figure 2: Frequence RCP in caregivers.

With respect to RCB, shoulders raised most often obtained $81.25 \%$ (13), as shown in Figure 3.

\section{RCB}

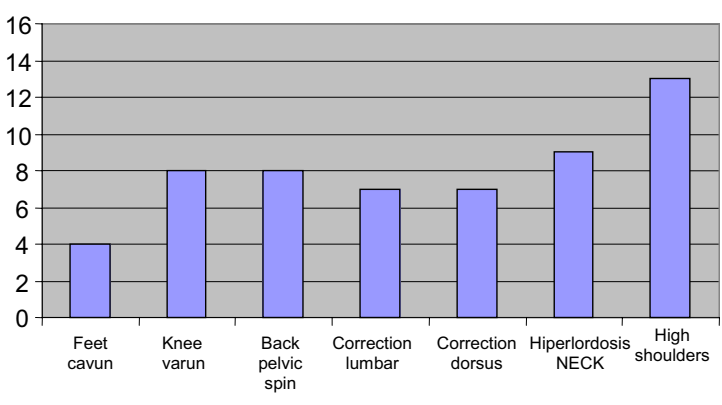

Figura 3: Frequence retraction CB.

Regarding the presence of other decreases lordosis diaphragm was detected by examining posture in $75 \%$ (12) of the sample. As for the tests, the tests of $\mathrm{CB}$, standing with abdcution $(\mathrm{AB})$ of arms and $\mathrm{CB}$, seated as the arms $\mathrm{AB}$ obtained the frequency of $50 \%$ of caregivers to offset sharp. The CB test, standing with adduction (AD) of the arms and the $\mathrm{BC}$, standing, with alignment of three points (occiput, scapula and sacrum) had $56.25 \%$ of the caregivers often marked for clearing. The $\mathrm{CB}$ test, seated with arms AD presented the results of $37.5 \%$ for minimum compensation. As for the trunk flexion test for the $\mathrm{CB}$, the most frequent alterations were the opening angle of the tibial-tarsal, open hip joint angle and the presence of flat areas, with $87.5 \%$ of caregivers presenting these changes, as shown Figure. 4:

\section{TEST SPINE FLEXION}

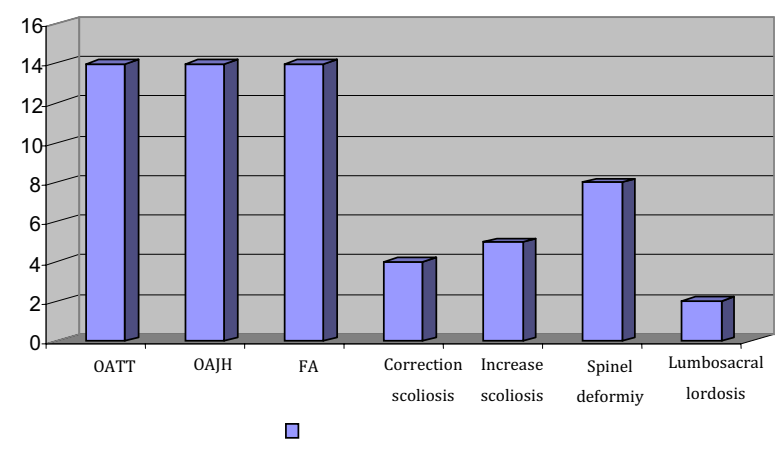

Figure 4: Frequence other problems in caregivers during test to $\mathrm{CB}$

Good posture has an important link in maintaining a healthy spine, since the burden to the spine can cause dysfunction, presenting most often painful symptoms, decreased resistance to fatigue of postural muscles, compromising, consequently, the efficiency of movement which may result in significant changes in body alignment [18].

The normal posture is maintained by strong muscles and flexible joints working properly, a balanced line of gravity and good postural habits. The changes in postural alignment can be secondary to structural malformation muscle even while performing simple tasks [16]. Muscles, ligaments and tendons are particularly vulnerable to the effects of repetitive pressure forces, while the bones and cartilage are susceptible to injury by applying forces compressor

The fact that the activity of caregivers have a high physical demands of the upper limbs and shoulder girdle in the handling of the elderly and other activities of asylum, creating heightened tension of muscles, would justify the higher prevalence of shoulder and rolled high as major downturns.

There was also tests for anterior and posterior chain, which most caregivers showed marked clearing in performing both tests. The opening angle of the tibial-tarsal, opening the hip joint and the flat areas were the most frequent 
changes to the trunk flexion test with $87.5 \%$. Such changes are related to retraction of muscles responsible for balancing lumbopelvic (hamstrings, psoas, piriformis, quadratus lumborum) and signs of spinal hypomobility (presence of flat areas) which creates imbalances that can generate static back pain [27] [12] [3] [15].

\subsection{Assessment diagram Corllet}

Regarding the evaluation of the diagram Corllet adapted the symptom with the highest frequency was fatigue or tiredness regions (17 and 20) that correspond to the legs, with $81 \%$ of the results. Pain in region 4 that corresponds to the lumbar spine, was frequent in $50 \%$ of caregivers, pain in the upper thoracic region (3) in $18.75 \%$ and $25 \%$ in the upper thoracic and cervical.

Table 2 shows the frequency of signs and symptoms relating it to the body region most frequently cited by caregivers.

Table 2

Frequency signs and symptom for body region.

\begin{tabular}{lccc}
\hline Signs e Symptom & Region & $\boldsymbol{N}$ & $\%$ \\
\hline Pain & 4 & 8 & $50 \%$ \\
Numbness & 10,15 & 5 & $31 \%$ \\
$\begin{array}{l}\text { Tingling } \\
\text { Sensation }\end{array}$ & 21 & 5 & $31 \%$ \\
$\begin{array}{l}\text { Burnings } \\
\text { Sensation }\end{array}$ & 3,4 & 3 & $19 \%$ \\
$\begin{array}{l}\text { Weight } \\
\text { Sensation }\end{array}$ & 2 & 7 & $44 \%$ \\
$\begin{array}{l}\text { Cramps } \\
\text { Decreased } \\
\text { movement }\end{array}$ & 15,10 & 1 & $6 \%$ \\
$\begin{array}{l}\text { Weak } \\
\text { strength } \\
\text { Muscle Fatigue }\end{array}$ & 6,7 & 3 & $19 \%$ \\
Edema & 11,12 & 6 & $38 \%$ \\
\hline
\end{tabular}

The results obtained by applying the diagram adapted Corlett confirmed the exposure of workers to the high physical burden that is consistent with studies of5) who point out that low back pain affects $60 \%$ to $90 \%$ of all adults during the time of life, and involvement among the most common degenerative diseases. Moreover, studies corroborate the findings in this study that the activity of high demand caregiver physical and mental work. \{] [9] [11]

\subsection{Pain Assessment}

In time, 93.75\% (15) of caregivers reported feeling pain in any region of the body, more than one year being the same classified as chronic.
With respect to pain in any region of the spine that was cited by all caregivers, referring to the intensity, $13.3 \%$ responded that their pain bothers some, that bothers $26.6 \%, 26.6 \%$ very uncomfortable, $6 \%$ and $6.66 \%$ very uncomfortable that the pain is unbearable. Regarding the type of pain, $73.3 \%$ replied that the pain is intermittent and the type that $66.6 \%$ (6) to be answered point-and 33.3\% (5) burning. As aggravating factors of pain, $53.3 \%$ of caregivers responded that the loading weight (handling of the elderly) the most frequent, followed by repetitive movements with $26.6 \%$. Were also cited as walking and stationary position with $6.66 \%$ each.

As factors of relief, the rest of the response earned $46.6 \%$ of caregivers, medication use $33.3 \%$ and $20 \%$ exercises. The pain radiated was present in $53.3 \%$ of the caregivers and the pain radiated into both arms had the highest percentage with $37.5 \%$ of the caregivers. All caregivers had at least one symptom associated with the headache the most frequent with $66.6 \%$ (10 caregivers).

When asked if the pain somehow prevented the fulfillment of their daily activities and work $53.3 \%$ of caregivers responded affirmatively. As sleep quality $86.6 \%$ between $5-8$ hours sleep per night, $40 \%$ on a soft mattress, $33.3 \%$ in hard mattress, $53.3 \%$ makes use of a pillow. $53.3 \%$ also report that sleep is sometimes hectic, where $13.3 \%$ use of medication. Only 20\% reported having a peaceful sleep.

All study participants responded to spend most of the day walking which is reflected in the higher frequency of fatigue and tiredness in the lower limbs (LL), Regions 20 and 17 of the diagram Corllet.

Finally when asked about the position they feel more pain $46.6 \%$ answered that they change from sitting to standing, standing up $33.3 \%$ and $33.3 \%$ sat.

The work of caregivers elderly is characterized by heavy lifting and / or handling of excessive loads, occurring on the structure osteomuscleskeletal trauma, especially in the spine.[19] [13] [17]. Several factors have been associated with the presence of chronic low back pain, such as age, sex, smoking, alcohol consumption, body weight, social class, education level, physical activity and work activities [2].

The pain of patients who most frequently seek the position of physiotherapist in pain, still pain, pain, arthritis, aches and pains due to the osteopathic musculoskeletal disorders. Different types of pain and the placement are still related to work activities. [6]

The pain caused by positioning these positions 
are maintained for long periods of time and repeated movements. It is known for the pain professional precursor of osteoarthritis and repetitive strain injuries. Occur due to excessive ligament tensions and imbalances of pressure on the joint surfaces. These pains are not present in the acute phase, gradually settle the patient need not know the moment it appeared, is not constant, goes away with rest and relieved by the change of position at work [6]. The home as a factor in relieving low back pain was the most cited presenting a percentage of $43.75 \%$ of the sample. This finding demonstrates that, according to the classification of Bienfait ${ }^{[6]}$, the pain is the type of caregivers positional. The fact that $50 \%$ of caregivers report that is radiated back pain (18.75\% for both the lower extremities, and for both upper limbs) may mean peripheral compression syndromes due to lumbar herniation.[12] [5]

The poor quality of sleep of $75 \%$ of caregivers and interference of pain in carrying out their activities of daily living and employment have been reported for $50 \%$ of workers demonstrates the degree of discomfort caused by pain and consequently a decrease in productivity which corroborates with others studies [13][14][17] [10].

States that stretches through the different postures practiced the Global Postural Reeducation (GPR) allows the chains lengthen shortened muscle to improve the instrument body morphology correcting, suppressing and releasing the joint stiffness.[29][30]. Method REPOSTURARSE (Postural Reeducation Sensory Perception) is used for technical or felt sense of body awareness, postures Global self postures, analytical work for static balance and postural corrections, among other fundamental techniques to integrate the new experiences gained in the course of work restructuring posture since acquired the corrections are incorporated into the body schema [3]

\section{Conclusion}

The main objective of this study was to evaluate pain in caregivers of elderly in a nursing home. It was felt that this work activity contributes to the development of back pain in these professionals, confirmed by the analysis of biomechanical and organizational risks are present in the workplace and the diagnosis of postural examination of caregivers who had a positive retraction of both the anterior and chain posterior chain and testing of anterior and posterior chain, significant shortening of both chains. Therefore, it is suggested to minimize these risk factors present in this production process, adopting some simple ergonomic measures, guiding them in the adoption of appropriate working postures. Moreover, it is recommended exercises in preparation for the workday, as well as restructuring posture, stretching exercises and strengthening analytical and global muscle using the method REPOSTURARSE thus allowing a better body awareness and minimizing the signs and symptoms present in these workers, improving their quality of life and therefore work performance.

\section{References}

[1] Abraão, J.[ et al]. Introdução a Ergonomia: da pratica a teoria. São Paulo: Blucher, 2009.

[2] Almeida, Isabela Costa Guerra Barreto et al. Prevalência de dor lombar crônica na população da cidade de Salvador. Rev. bras. ortop. [online]. 2008, vol.43, n.3, pp. 96-102. ISSN 0102-3616. doi: 10.1590/S0102-36162008000200007.

[3] Almeida, Laís Cristina. Reeducação postural e sensoperceptiva: fudamentos teóricos e práticos. $1^{\mathrm{a}}$ ed, Rio de Janeiro, Medbook, 2006.

[4] Almeida, Vanessa; Dias, Elizabeth Costas; Godoy, Cervindo Bicalho. Desafio da abordagem multidisciplinar na lombalgia ocupacional. Revista de Enfermagem, Belo Horizonte, v.1, n. 7, p. 6772, jan/jul, 2003.

[5] Barbosa, Juliana Andrade. Hérnia de disco. Disponível

http//www.wgate.com.br/conteúdo;medicinaesaude /fisioterapia/traumato/hérnia_de_disco. Acesso em 07/04/2009.

[6] Bienfait, Marcel. A dor em terapia manual. Disponível

www.centrodesaopaulo.com.br/artigos/artigos2. acessado em 14/12/2009.

[7] Bittar, Aparecida Donizete da Silva et al. Influência da intervenção ergonômica e o exercício físico no tratamento do estresse ocupacional. Reabilitar, São Paulo, ano6, n24, p.35-43, jul/set, 2004.

[8] Breder, Vanessa Ferreira; Oliveira, Débora Feliciano; SILVA, Marco Antônio Guimarães da. Atividade física e lombalgia. Fisioterapia Brasil, Rio de Janeiro, v.6, n. 2, p. 157-161, mar/abr, 2005.

[9] Camargo RCVF. Implicações na saúde mental de cuidadores de idosos:Uma necessidade urgente de apoio formal. SMAD, Rev. Eletrônica Saúde Mental Álcool Drog. (Ed. port.) [Internet]. 2010 [acesso em: 28.08.2011] ; 6(2):231-54. Disponível em:

http://redalyc.uaemex.mx/redalyc/pdf/803/8031449 2002.pdf.

[10] Cardia, Maria Claudia Gatto. Manual da escola de postura da UFPB. 3 ed. Paraíba: UFPB, 2006.

[11] Colome, ICS et al; Cuidar de idosos institucionalizados: características e dificuldades dos cuidadores. Rev. Eletr. Enf. [Internet]. 2011 abr/jun;13(2):306-12. [Acesso em: 28.08.2011] Disponivel http://www.fen.ufg.br/revista/v13/n2/pdf/v13n2a17 .pdf

[12] Corrigan, Brian; Maitland, Geoff. Transtornos musculoesqueleticos da coluna vertebral. Trad. Douglas Arthur Omena Futuro. Rio de Janeiro RJ: Revinter, 2005). 
[13] Couto, Hudson de Araújo. Como implantar ergonomia na empresa- A prática dos comitês de ergonomia. $1^{\text {a }}$ ed, Belo Horizonte: Casa da Imagem, 2007, pp. 97-108.

[14] Deliberato, Paulo C. P. Fisioterapia preventiva: fundamentos e aplicações. $1^{\text {a }}$ ed, São Paulo: Manole, 2002, pp.101-199.

[15] Dolken, Mechthild. Fisioterapia em Ortopedia. São Paulo: Santos, 2008

[16] Gross, Jeffrey et. al Exame músculo esquelético. Porto Alegre: Artmed, 2001; pp. 419-439.

[17] Iida, Itiro Ergonomia: projeto e produção. São Paulo: Editora Edgard Blucher, 2005.

[18] Kisner, Carolyn; Colby, Lynn Allen Exercícios Terapêuticos: fundamentos e técnicas. $2^{\mathrm{a}}$ ed.,São Paulo: Manole, 1992, pp. 429-499.

[19] Knoplich, José. Enfermidades da Coluna Vertebral: uma revisão clinica e fisioterápica. $3^{\mathrm{a}}$ ed. São Paulo SP: Robe editorial, 2003.

[20] Maitland, Geoff et al. Manipulação vertebral de Maitland. Trad. Maria de Fátima Palmieri Meirelles. $6^{\mathrm{a}}$ ed. Rio de Janeiro - RJ: Medsi, 2003.

[21] Melo, PB et al; Percepção dos cuidadores frente s dificuldades encontradas no cuidado diário de idosos dependentes institucionalizados.Estud. interdiscip. envelhec., Porto Alegre, v. 13, n. 2, p. 259-274, 2008. [acesso em: 28.08.2011] Disponivel em: http://seer.ufrgs.br/RevEnvelhecer/article/view/5375.

[22] Mendes, GD; Miranda, SM; Borges; MMMC. Saúde do cuidador de idosos: Um desafio para o cuidado. Revista Enfermagem Integrada - Ipatinga:UnilesteMG. V.3 -N.1 -Jul;Ago 2010 [acesso em: 28.08.2011] Disponível em: http://www.unilestemg.br/enfermagemintegrada/artig o/v3/04-saude-cuidador-idosos-desafio.pdf
[23] Neto,C.F.M.[ et al ]. Ambiente de trabalho e qualidade. Curso de Gestão da qualidade e produtividade.Departamento de Engenharia da Produção, UFPB, 2004 acesso em: set/2010 disponível online: www.ct.ufpb.br/ceset/disc.../ambiente_de_trabalho_e qualidade.doc

[24] Norkin, Cynthia C.; Levangie, Pamela K. Articulações - estrutura e função - uma abordagem prática e abrangente. Rio de Janeiro: $2^{\mathrm{a}}$ ed ,Revinter, 2001, pp. 190-203.

[25] Resende, MCF; Dias EC. Cuidadores de idoso: Um novo-Velho trabalho. Physis Revista de Saúde Coletiva, Rio de Janeiro, 18 [ 4 ]: 785-800, 2008 [Acesso em: 28.08.2011] Disponivel em: http://www.scielo.br/scielo.php?script=sci_arttext\&pi $\mathrm{d}=\mathrm{S} 0103-73312008000400010$

[26] Rodrigues, Elizabete Pratavieira. Cartilha LER/DORT: prevenção é o melhor remédio. 1 ed. São Paulo: FEAAC, 2004..

[27] Santos, Angela. Diagnostico clinico postural: um guia pratico. Sao Paulo-SP:Summus, 2001.

[28] Sommerhalder, Cínara. Significados associados a tarefa de cuidar de idosos de alta dependência no contexto familiar. Campinas, Faculdade de Educação/UESC. 2001. Dissertação de Mestrado.

[29] Souchard, Ph. E. O Stretching global ativo: a reeducação global a serviço do esporte. Trad. Sonia Pardellas. $2^{\mathrm{a}}$ ed, São Paulo: Manole, 1996.

[30] Souchard, P. e Ollier, M. As Escolioses. Sao Paulo: E Realizações, 2003. 